\title{
室内音場の受音点に到来する個々の反射音の特性抽出手法の開発 DEVELOPMENT OF METHOD FOR DETECTION OF CHARACTERISTIC OF RESPECTIVE SOUND WAVE ARRIVED AT RECEIVING POINT IN A ROOM SOUND FIELD
}

\author{
羽入敏 樹*，木村: 翔**，関口克明*** \\ Toshiki HANYU, Sho KIMURA and Katsuaki SEKIGUCHI
}

This paper describes the development of a method for detecting individual characteristics of reflected sounds arriving at a sound receiving point in a sound field in a room. The development is based on the regular tetrahedron peak point method, which we developed, for computing virtual sound sources, in combination with the spherical array microphone system, a method for measuring impulse responses by directions.

In this method, we compute the arriving time and direction of each reflected sound by the regular tetrahedron peak point method in order to grasp the individual characteristics of each reflected sound arriving at a sound receiving point, then measure the directional response through spherical arrày microphon system in the direction of each reflected sound, separating the reflected sound of the extracted object from those of others, and finally separating it by a suitable length of time window from the arrival time of each reflected sound, thus extracting the time series characteristics of each individual reflected sound.

Further, we give some single plate reflection experiments, verification experiments of extraction accuracy at an actual sound field, and analyses of virtual sound source distribution by fre. quencies in an actual sound field, thus showing a possibility in which physical characteristics of a sound field can be observed in detail including directional information at the initial response.

Keywords : virtual sound source, reguler tetrahedron peak point method, spherical array microphone system, reflective sound, impulse response, spatial information

仮想音源，正四面体頂点法，球面上配置マイクロホンシステム，反射音，インパルス 応答，空間情報

\section{1. はじめに}

近年，ディジタル信号処理技術の進歩により，音源と 受音点間のインパルス応答をディジタル信号として精度 良く測定できるよううになり，時間，エネルギー，周波数 に関する種々の音響物理指標が算出可能となっている。

この単一のインパルス応答は, 音場空間の様々な方向 から時々刻々受音点に到来する多数の反射音による振幅 変化を，ある時間刻みで記録した反射音群の総合的な情 報である。そのため，ある時刻の振幅が単一の反射音に よるものか，複数の反射音の干渉によるものかはわから ない。さらに，その振幅がどの方向から到来した反射音 のものかもわからず，聴感上重要と言われている音場の 方向情報を得ることはできない。したがって，音場の物
理的特性をより詳細に把握するためには，反射音がイン パルス応答として単一時系列に合成される前の，受音点 に到来する個々の反射音の到来方向とそのレベル，特性 を知る必要がある。

筆者らは，これまで，個々の反射音の到来方向とその レベルを算出する実用的な解析手法として，山崎らの近 接 4 点法”を発展させた正四面体頂点法”を開発し，音 場のより詳細な把握を試みてきた。

近接 4 点法は, 4 点でのインパルス応答の時間構造の わずかな違いから, 短時間相互相関の手法を用いて, 音 波の抽出とその到来方向の算出を行うが, この手法では 時間経過とともに複数の波形が重なった場合，相関の値 が下がって反射音の特定が難しくなり，音波の抽出と音
* 日本大学大学院 $\cdot$ 松下通信工業 $\cdot$ 工修

日本大学理工学部 教授・工博

*** 日本大学理工学部 教授. 工博
College of Science and Technology Nihon Univ., Matsushita Communication Industrial Co. Ltd, M. Eng.

Prof., College of Science and Technology Nihon Univ., Dr. Eng.

Prof., College of Science and Technology Nihon Univ., Dr. Eng. 
波の到来方向の両方に関しての精度が低下する。

一方，正四面体頂点法は，複数の音波が重なった場合 でも個々の音波の到来方向に関する精度の確保を重視 し, 反射音の特性の抽出は行わずに, 音波の到達時間と レベルと 4 点の幾何学情報を用い，音波の到来方向とレ ベルのみを精度良く抽出する方法である。すなわち正四 面体頂点法は，個々の音波の到来方向を精度良く算出す るため, 時間とレベルに着目しており，周波数情報は全 く得られない。

そこで, 正四面体頂点法の方向情報を補完するために， 筆者らは周波数情報を含んだ方向別のインパルス応答を 測定する手法として, 球面上配置マイクロホンシステ ム゙'を開発して実用化してきた。

この手法は，一度測定を行えば，3 次元の全空間を対 象とした任意方向のインパルス応答が何回でも算出可能 で，3 次元空間の全方向に対してほぼ同等の指向特性を 実現でき,さらに指向性受音方向からの音波に対しては， 何らその特性に影響を及ぼさずに収音することができ る。これにより，時間経過による周波数特性の変化等を 方向別に把握することができる。しかし，得られる方向 別インパルス応答は，任意方向のエリアから到来する音 波群の総合的な情報であり，個々の反射音の詳細な情報 は得られない。

そこで筆者らは，実際に受音点に到来する個々の反射 音の特性を把握するため，正四面体頂点法で反射音の到 達時間と到来方向を算出した後, それらの方向に球面上 配置マイクロホンによる指向性受音を行い，抽出対象の 反射音とその他の反射音を空間的に分離し，さらに反射 音の到達時間から適当な大きさの時間悹により時間的分 離を行って, 個々の反射音の時系列特性を抽出する手法 を開発して，実音場でその有用性を確めたので，その結 果について報告する。

\section{2. 個々の反射音特性の抽出手法}

ホール等の実音場において，個々の反射音の特性を知 るためには，受音点に到来する多数の反射音の中から一 つ一つの反射音波形を分離抽出する必要がある。そのた めの手法として, 相関手法による分離, 指向性受音によ る空間的分離, 時間的分離等の手法が考えられる。

相関手法による分離は，反射音が単独で存在する場合 は，その反射音波形の継続時間を判定して，波形を切り とる時間空を変化させながら抽出できるが，複数の反射 音が干渉している波形から分離抽出するのは困難であ る。

指向性受音による空間的分離は，抽出したい反射音の 到来方向以外からの反射音を分離できるが，そのために は，あらかじめ反射音の到来方向を知っておく必要があ る。また，指向性受音だけでは方向別インパルス応答が
算出されるだけで，個々の反射音の特性とはいえない。 時間的に分離する方法は，あらかじめ反射音の到達時 間がわかっており，かつ他の反射音がその時間に到来し ない場合には有効である。しかし，ホール等の実音場に おいては，一般に同一時間に多数の反射音が到来してい ると考えられるので，時間的分離だけでは反射音の抽出 は難しい。

以上のことから，これらの手法を個々に用いただけで は，精度良く反射音波形を抽出することは難しいことが わかる。しかし，これらの手法を組み合わせて，空間的 分離を行った後に時間的分離を行い，さらに相関手法に よって波形を切り出せれば，より精度良く反射音を抽出 することができると考えられる。

その前提として, 反射音の到達時間と到来方向を精度 良く測定する必要がある。筆者らが音場の方向情報の定 量化の一環として用いている正四面体頂点法 ${ }^{21}$ は, 反射 音の特性の抽出を行わずに，複数の反射音が重なって到 来した場合でも,デコンボリュージョン手法と 4 点の受 音点相互の幾何学情報から, 個々の反射音の到達時間を 精度良く検出することができる，到達時間と到来方向に 関する精度をとくに重視した仮想音源の算出手法であ る。

したがって, 正四面体頂点法で得られる反射音の到達 時間と到来方向の情報をもとにして，空間的分離，時間 的分離,相関手法による分離を組み合わせることで,個々 の反射音特性の分離抽出ができると考えられる。

正四面体頂点法は，仮想音源を算出する際，図一1に 図すように,レベルとして波形の振幅値を参照しており， 周波数情報は得られていないので，この正四面体頂点法 に周波数情報を付加するためには，個々の反射音の特性 を考慮した波形としての抽出が必要である。

次に，空間的分離のためには指向性受音方法を確立す ることが必要であるが，そのための指向性受音方法が備 えるべき必要条件を考えてみると，

（1）測定現場で，正四面体頂点法で算出されたそれぞ れの反射音に対して, 繰り返し指向性受音を行うのは現

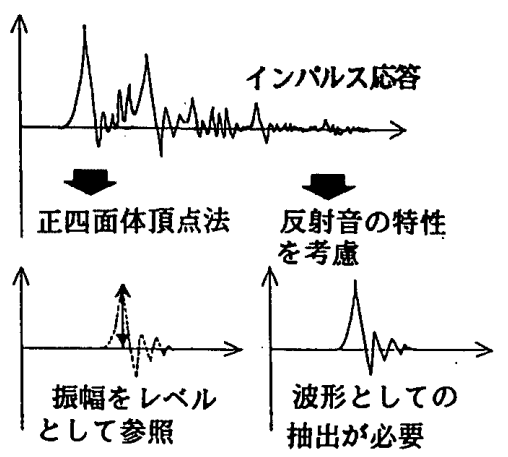

図一1 正四面体頂点法における仮想音源レベルの算出と反射音 波形の抽出 


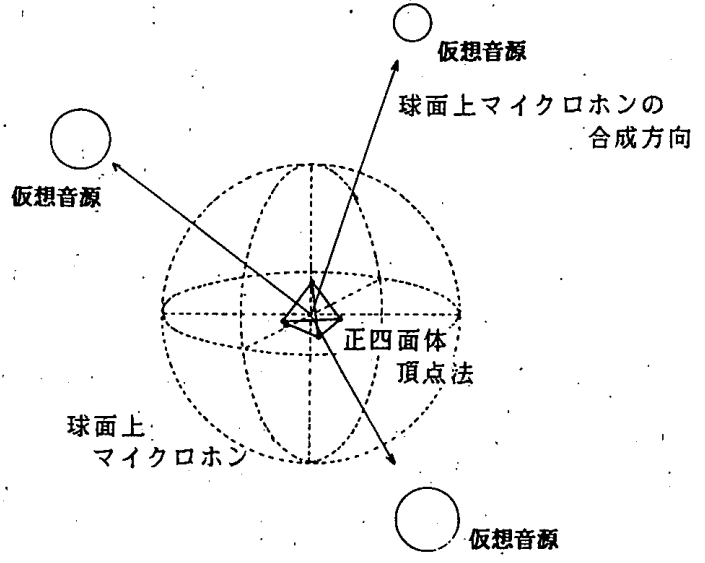

図一2，本手法における測定方法の概念図

奏的ではないので，一度の測定によって後処理で何回で も指向性受音波形が算出できること。..

（2）音場の全空間を等価な対象として正確に把握する ために，3次元空間のあらゆる方向から到来する音波に 対して，同様の指向特性で収音できること。

（３），できるだけ広い帯域にわたって同様の指向特性で あるこ்よ。

（4）指向角についてある程度の制御ができること。

（5）指向性受音することで反射音の特性が変化しない こと。

などがあげられる。

これらの条件を満たすために，我々は，球面上配置マ イクロホンシステム゙'を指向性受音手法として用いるこ とにした。ごの手法は, 複層球面上にランダムに設定し た 128 点の各受音点で一度測定を行えば，3 次元の全空 間を対象とした任意方向のインパルス応答が何回でも算 出可能で，3 次元空間の全方向に対してほぼ同等の指向 特性を実現でき, 球の半径を変えることで指向角の制御 が可能で, 各周波数帯域ごとに同等の指向特性を実現で きる。また，指向性受音に際しては，球面上の各受音点 でのインパルス応答を，音波が通過する際の各受音点間 の時間差を考慮して合成するという手法を用いているた め, 指向性受音方向からの音波に対しては何らその特性 に影響を及ぼさずに収音することができる。

これらの点を踏まえ, 正四面体頂点法と球面上配置マ イクロホシシステムの特徵を活かし，両者を組み合わせ て用いることによって，個々の反射音の特性を精度良く 抽出できるものと考えられる。

測定は図一2に示すように，正四面体頂点法と球面上 配置マイクロホンシステムによる収音を, 解析の際に想 定する座標軸が一致するように同一のポイントで，正四 面体の重心と球の中心を一致させ，それぞれ別々に行う。

解析は図一 3 に示すように，正四面体頂点法で仮想音 源位置を算出した後, 算出された個々の仮想音源に向け て球面上配置マイクロホンの指向合成を行い, 指向性受
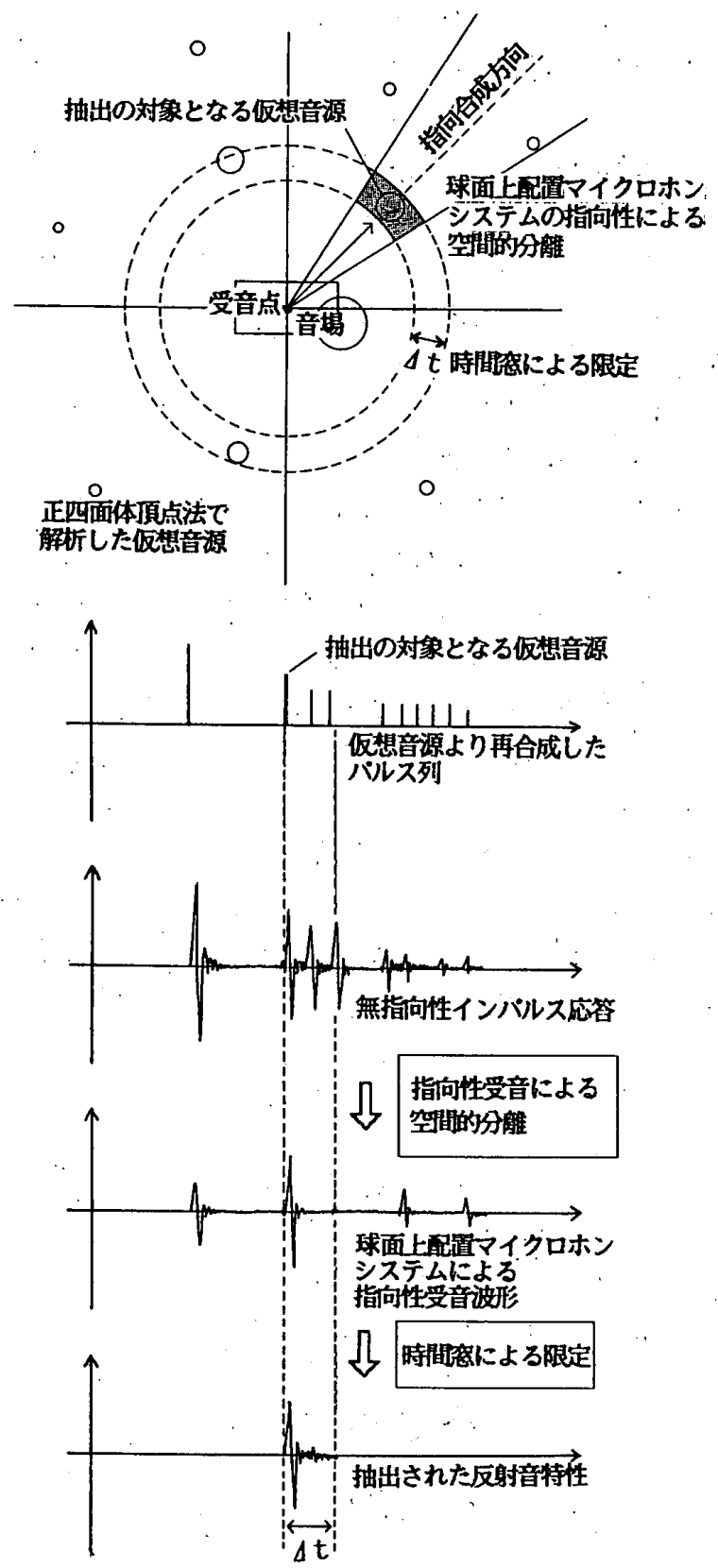

図一3 反射音抽出手法の概念図

音による空間的分離を行う。さらに, 仮想音源の時系列 上の位置は正四面体頂点法で算出しているので, その時 間から適当な大きさの時間空 $\Delta t$ により時系列上での分 離を行って, 反射音の時系列特性を抽出する。この時, 波形の継続時間が未知の場合, 相関手法により時間空 $\Delta t$ を決定することも考えられる。

このように, 空間的分離と, 時間的分離を組み合わせ て行うことによって，抽出する対象となる仮想音源の存 在するエリアを限定し，個々の反射音の特性の抽出が可 能となる。さらに，音波の到来方向に向けてそれぞれ指 向合成を行い，収音することになるので，抽出の対象に なる仮想音源は，指向特性の影響を受けない。また、こ のように反射音の到来方向の算出亡, その波形としての 時系列特性の抽出を別過程としていることにより，反射 
音の到来方向とその特性の両方を，より精度良く算出す ることができる。

\section{3. 単板反射実験による検討}

本手法の検討を行うために，壁からの反射音の影響を 分離できる体育館のアリーナ中央付近において，図一4 に示すように板の法線方向から 15 度，30度方向にあた る受音点で，単板 $(56 \mathrm{~cm} \times 200 \mathrm{~cm})$ からの反射音を， 正四面体頂点法と球面上配置マイクロホンシステムによ り測定し，反射音特性の抽出を行った。

図一5に正四面体頂点法で解析した仮想音源を示す。 これを見ると 15 度，30 度方向ともに，直接音と床から の反射音 (反射音(1))，単板からの反射音（反射音(2)）, さらに単板と床に反射した音波（反射音(3)）による仮想 音源が算出されており, 音源, 反射板, 受音点が必ずし も幾何学的反射位置関係に無くても，波面としての反射 音が到来すれば，仮想音源が算出できることがわかる。

また， 15 度と 30 度方向の結果を比較すると, 直接音 と床からの反射音（反射音(1)）のレベルは 15 度と 30 度 方向でほぼ同じレベルであるが，単板からの反射音（反 射音(2)）と単板と林に反射した反射音（反射音(3) のレ

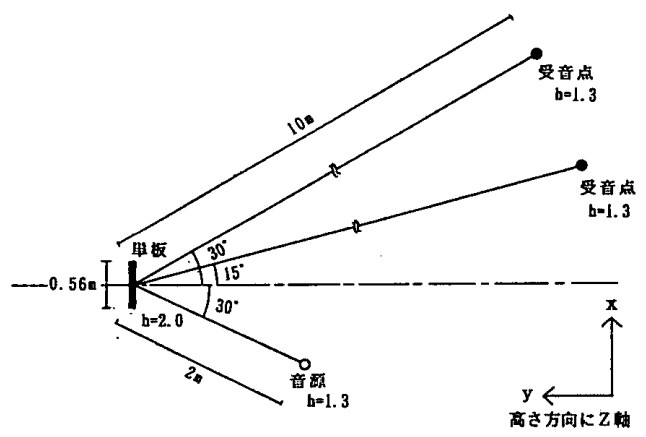

図一4 単板反射実験の配置図
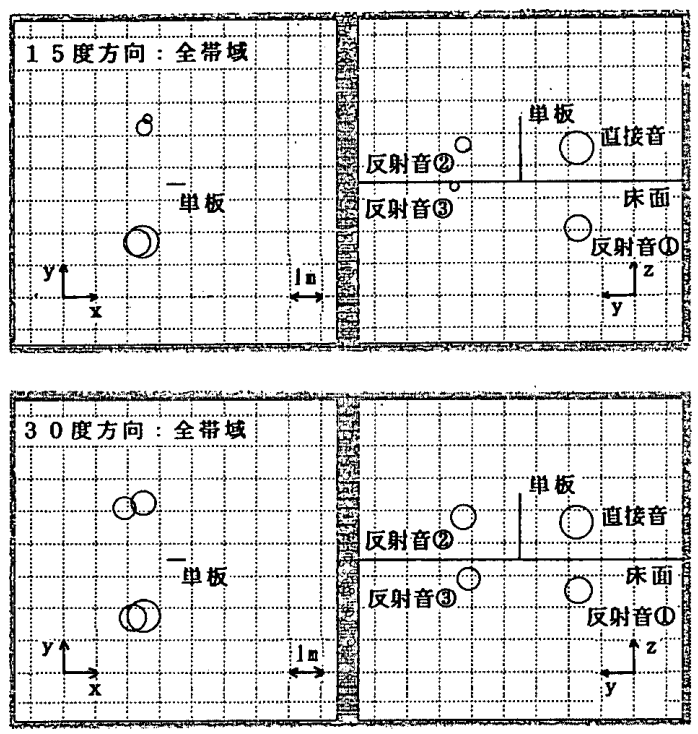

図一5 単板反射実験における各受音点で正四面体頂点法により 算出された仮想音源
ベルは，幾何学反射位置にある 30 度方向に比へ， 15 度 方向のレベルの方が小さい。これは，反射音が幾何学反 射方向には大きなレベルで反射し，幾何学反射位置から ずれるとレベルが小さくなることを示している。

次に，これらのそれぞれの仮想音源に向けて，球面上 配置マイクロホンシステムを用いて指向性受音を行い, 抽出した反射音波形と再合成波形を，無指向性の実測波 形とともに図一6に示す。なお，反射音波形は直接音デー 夕と同じデータ数の 512 データ以内で収束しているた め，512 データの時間空で切りとっている。これらを見 ると，反射音が波形として分離抽出されていることがわ かる。また，それらを再合成した波形と，無指向性の実 測波形もほぼよい対応を示している。

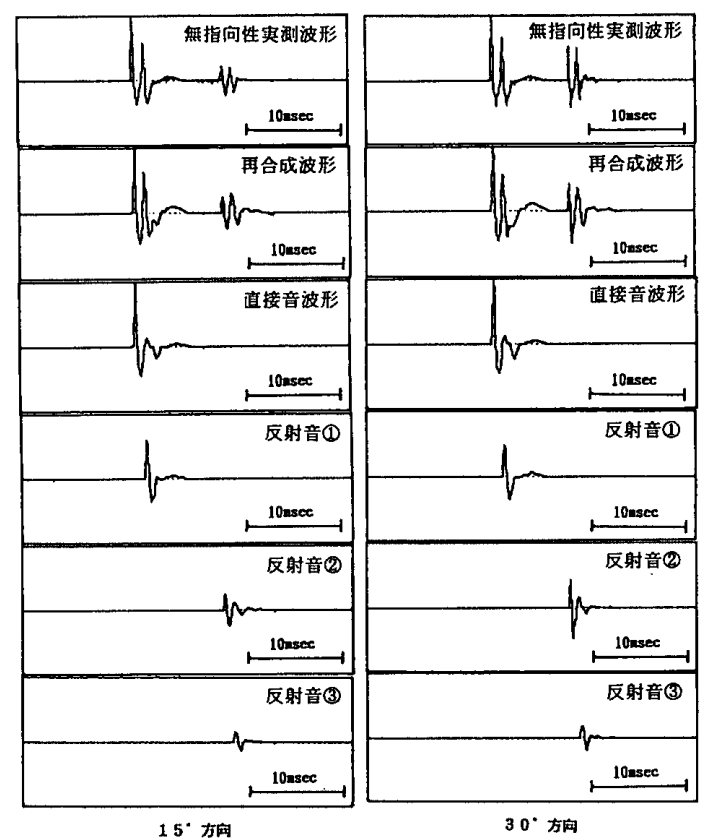

図一6 抽出した反射音波形と再合成波形
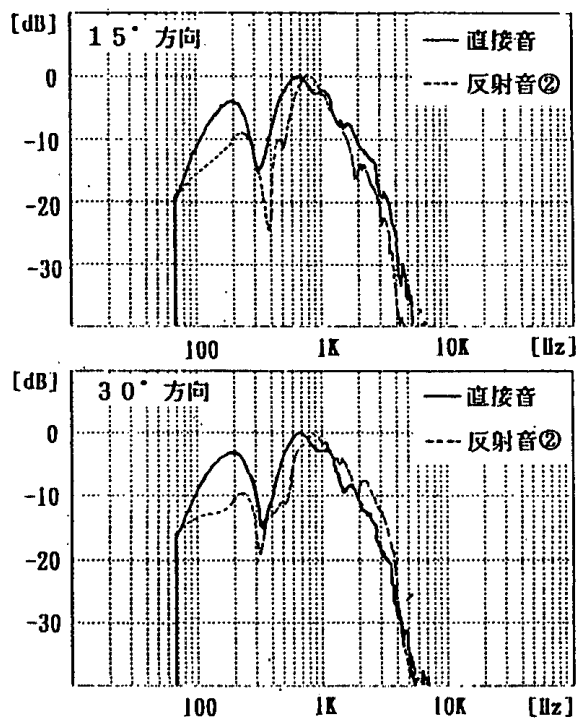

图一7 15 度， 30 度方向における直接音と反射音(2)のパワース ペクトルの比較 


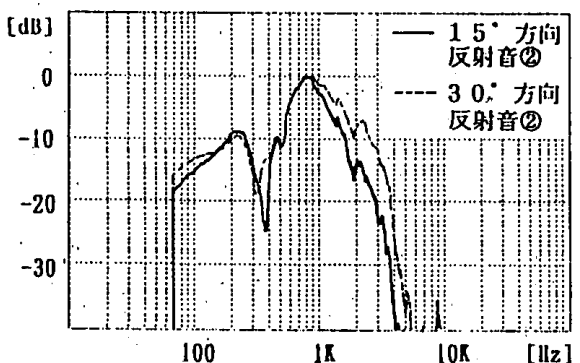

図-8 15 度，30 度方向の反射音(2)のパワースペクトルの比較
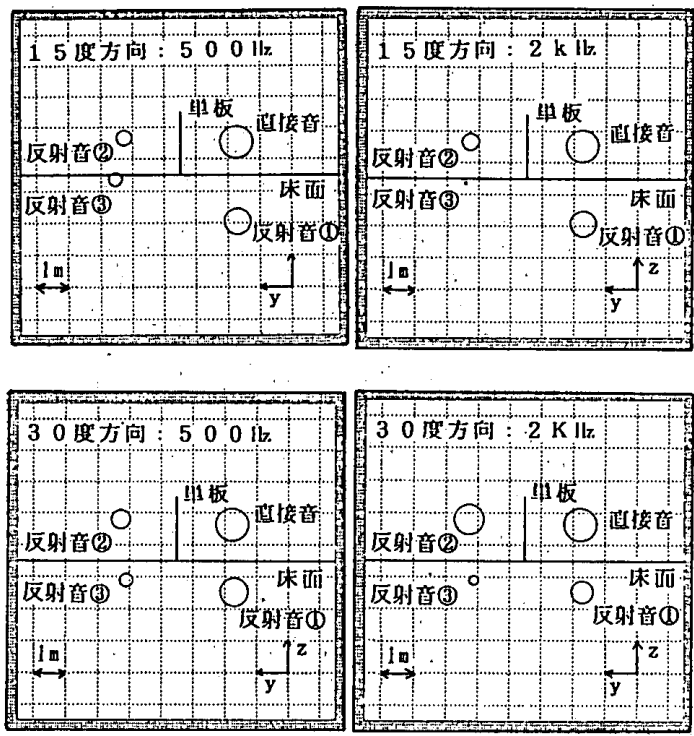

図一9 15 度； 30 度方向の周波数別仮想音源分布

15 度，30 度方向の反射音(2)と直接音のパワースペク トルを比較したものをそれぞれ図一7，図一8に示す。

図一7をみると，直接音に比較して，15 度，30度方向 ともに反射音(2)の低音域においてレベルが減衰してい る。これは，箪板の幅 $56 \mathrm{~cm}$ に相当する波辰を持つ音 波の周波数が約 $600 \mathrm{~Hz}$ となり，これより長い波長の音 波は，この単板では有効に反射することができないこと を示している。また，図一8では，幾何学反射位置にあ る 30 度に比較して, 幾何学反射位置にない 15 度での反 射音の方が, 高音域においてレベルが小さくなっている。 これは，一般に反射板に対する音波の反射指向特性は， 高音域ほど幾何学反射方向にシャ一プな指向特性となる ことを裏付けている。

さらに，反射音のオクターブバンドレベルを仮想音源 のレベルとし, $500 \mathrm{~Hz}$ と $2 \mathrm{kHz}$ のオクターブ帯域の周 波数別仮想音源を求めたものを図一9に示した。15度方 向と 30 度方向を比較してみると，幾何学反射位置にあ る 30 度に比較して, 幾何学反射位置にない 15 度での反 射音の仮想音源レベルの方が小さくなっており，その傾 向は $500 \mathrm{~Hz}$ 帯域より $2 \mathrm{kHz}$ 帯域でより顕著である。

以上のことから，本手法により音波の単板に対する周 波数ごとの，また角度ごとの反射特性の違いをとらえる ことができたと考えられる。

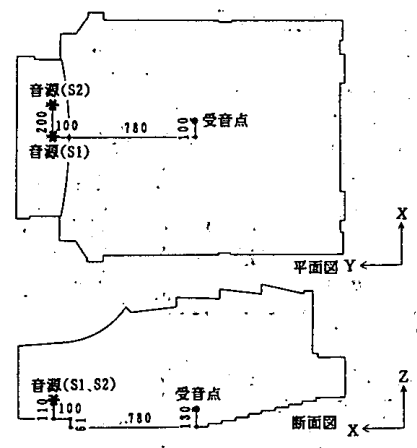

図一10 小ホールにおける実験配置図

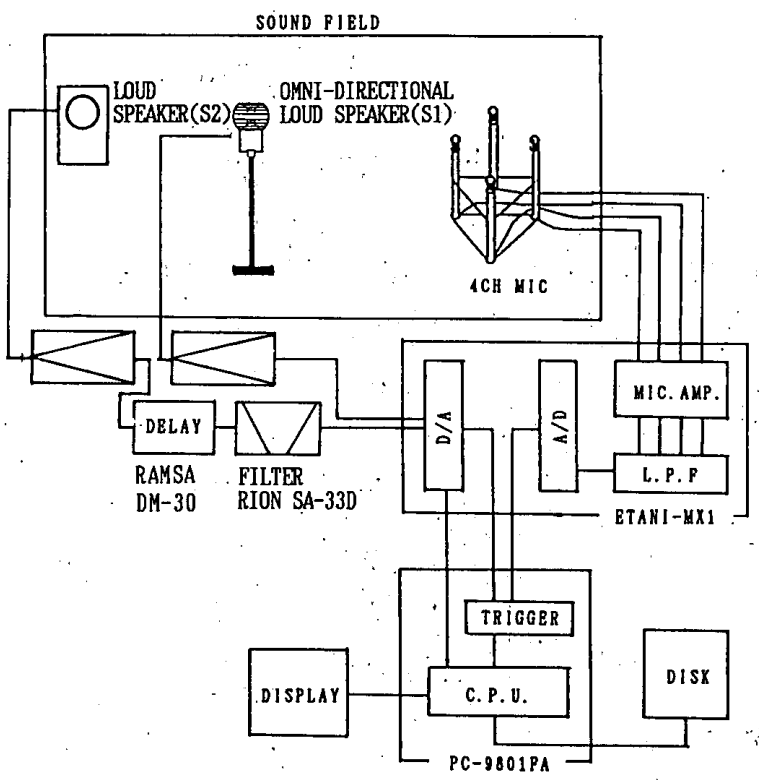

図一11検証実験における正四面体頂点法のブロックダイアヴ ラム

\section{4. 実音場での抽出精度に関する検討}

本手法による実音場での反射音抽出精度を検証するた め，比較的初期の段階から反射音密度が大きくなると予 想される小ホールにおいて夷験を行った。また, 奏音場 では，音源より音が発せられてから，受音点に到来する までの反射音の密度は, 時間とともに変化しているもの と考えられるので, そのそれぞれの反射音密度の中で, 反射音特性の抽出精度の検証を行う必要がある。

そこで，図一10に示すようにステージ上に2つの音 源S $1, \mathrm{~S} 2$ を設定し，S1 を通常のインパルス応答を測 定する際の音源, S 2 を S 1 から出た多数の反射音の中 に埋もれている抽出対象の反射音用音源と仮定し，ホー ルのほぼ中央点で本手法による測定を行った。

正四面体頂点法と球面上配置マイクロホンシステムの 測定ブロックダイヤグラムをそれぞれ図-11, 図一12 に示す。音源 S 2 から出た音を，S1によるインパルス 応答の中の任意の時間に到来した反射音と仮定するため に，音源 S 1 に対し任意のディレイを設定できるように した。なお，今回はディレイを $50 \mathrm{msec} ; 100 \mathrm{msec}, 200$ $\mathrm{msec}, 500 \mathrm{msec}$ の 4 パターンに設定し，それぞれのパ 


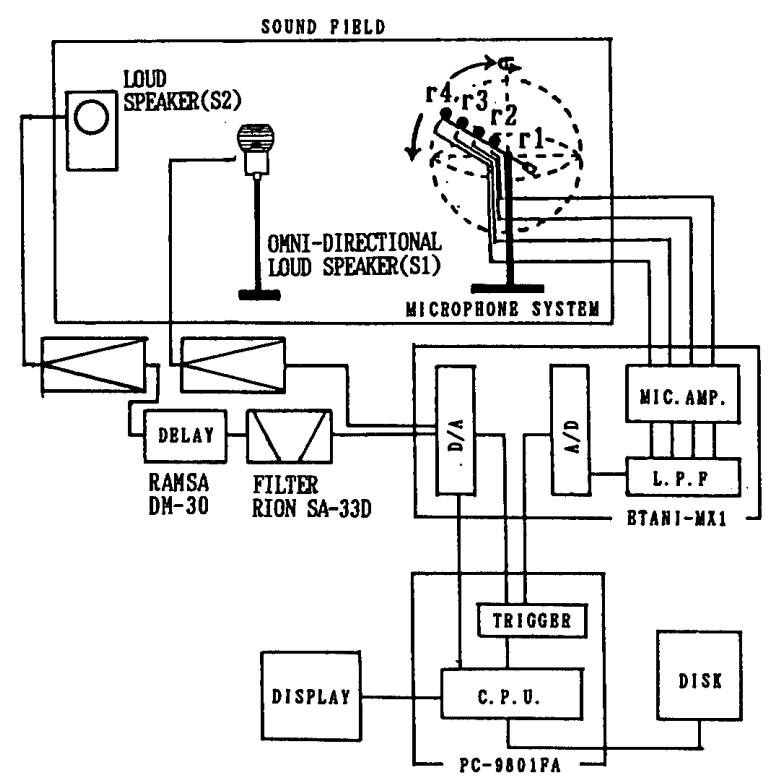

図一12 検証実験における球面上配置マイクロホンシステムの ブロックダイアグラム

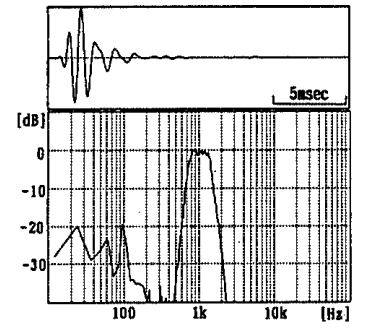

図一13 抽出する $1 \mathrm{kHz}$ トーンパースト波形とパワースペクト ル

ターンについて測定を行った。

音源は，S1については $80 \mu \mathrm{sec}$ 幅の三角波を用い， S 2 については波形抽出精度を検証するために，あらか じめ抽出する反射音波形を知っておいて，それと比較す る必要があることから，80 $\mu \mathrm{sec}$ 幅の三角波に $1 \mathrm{kHz}$ の オクターブバンドフィルタを通し，図一13に示すよう な $1 \mathrm{kHz}$ のトーンバースト波形を用いることにした。 音源 S 2 のレベルは, 図一14に示すように各ディレイ 設定パターンごとに距離減衰等を考慮し，S1によるイ ンパルス応答の中に埋もれるように設定した。図中の トーンバーストが埋もれている時間範囲の拡大波形を見 ても，S 2 によるトーンバースト波形はその他の反射音 と干渉していて，はっきりとは認められない。この波形 の中から，本手法によって図一13のトーンバースト波 形の抽出を試みた。

S 1 のみを音源としたときの正四面体頂点法による仮 想音源分布を図一15に示す。これを見ると，仮想音源 が原点付近に集中して多く算出されているが，これは初 期応答の段階から反射音が受音点に多数到来しているこ とを表している。

次に，音源 S 1 と各ディレイを設定した音源 S 2 を同
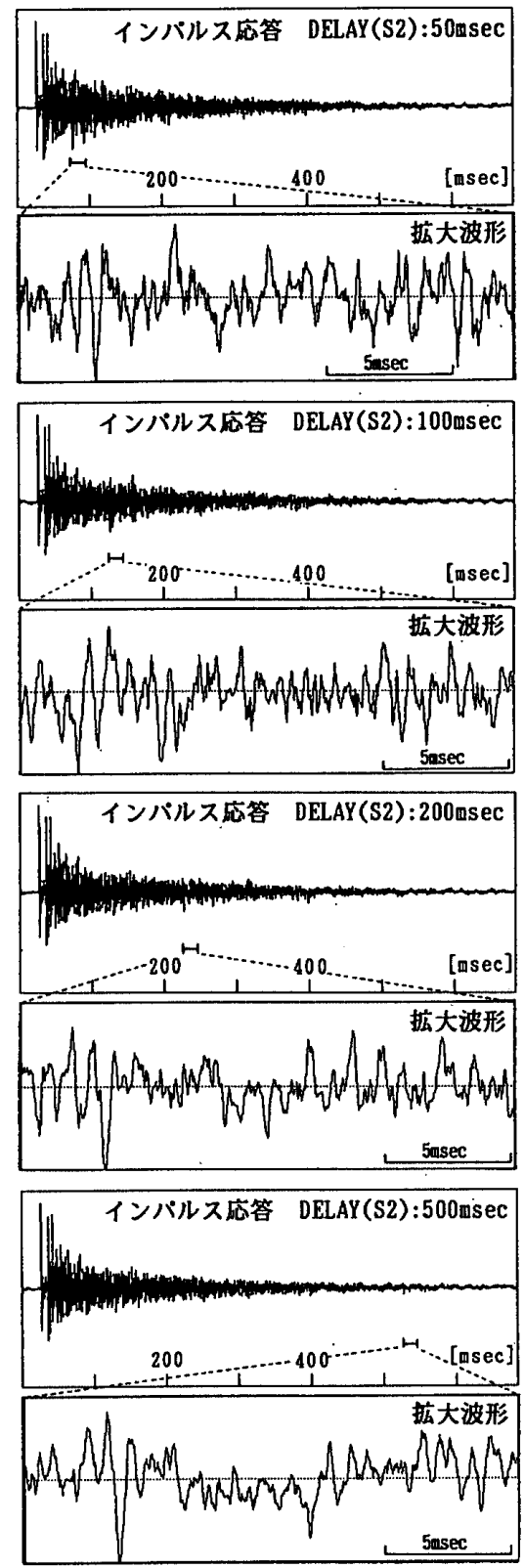

図一14 各ディレイ設定パターンごとの無指向性インパルス応 答とトーンバーストが埋もれている時間範囲の拡大波 形

時に用いた場合の正四面体頂点法による仮想音源の中か ら, S 2 方向の指向角 20 度の範囲に存在する仮想音源 のみを表示したものを図一16に示す。ここで,ディレ イ設定 $500 \mathrm{msec}$ の仮想音源分布図だけは表示範囲の都 合上縮尺が異なっている。また，図中には受音点と S 2 を結んだ直線を破線で示し，S 2 による仮想音源に矢印 でマークしてある。さらに，S2による仮想音源は，受 音点かららみて S 2 方向の延長線上に各ディレイ設定に応 じた距離だけ遠くに存在するはずであるので，その仮想 音源座標 $(X, Y, Z)$ の理論値を算出し, 正四面体頂 点法で算出された S 2 の仮想音源座標 $(X, Y, Z)$ と 比較して付記した。

これを見ると, 受音点とS 2 を結んだほぼ直線上の各 

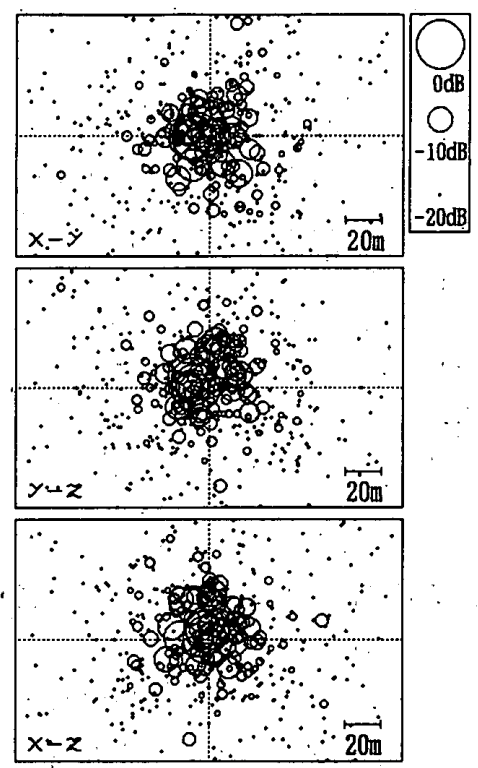

図一15 S1 のみを音源としたときの正四面体頂点法による仮 想音源分布
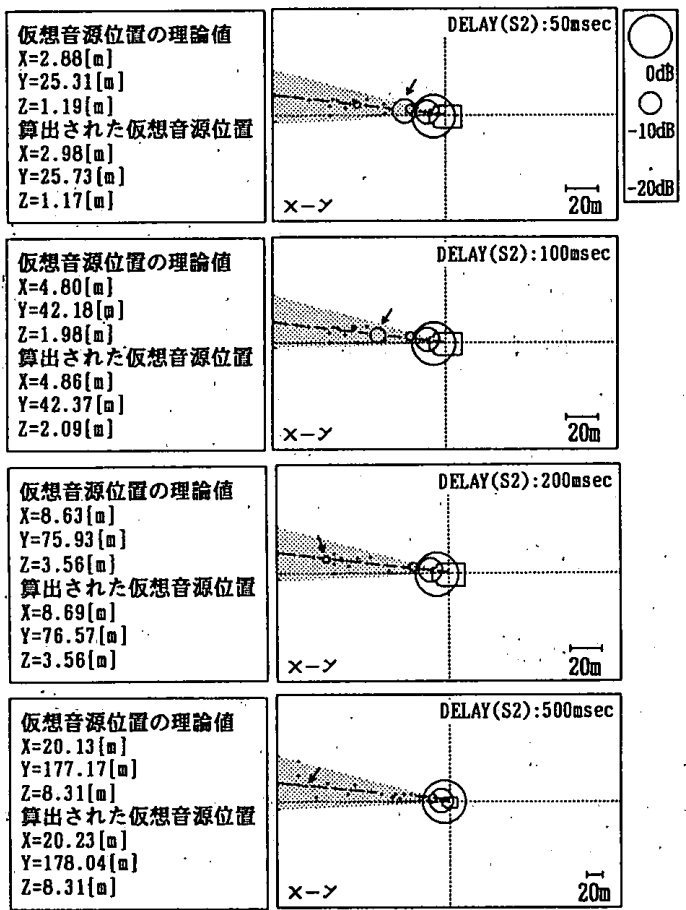

図一16 各ディレイ設定パターンごとの仮想音源分布（(S 2 方 向に指向角 20 度の範囲）とS 2 による仮想音源座標の

- 理論值と测定値

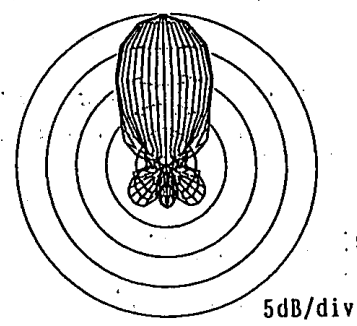

図一17 今回用いた球面上配置マイクロホンシステムの指向特 性
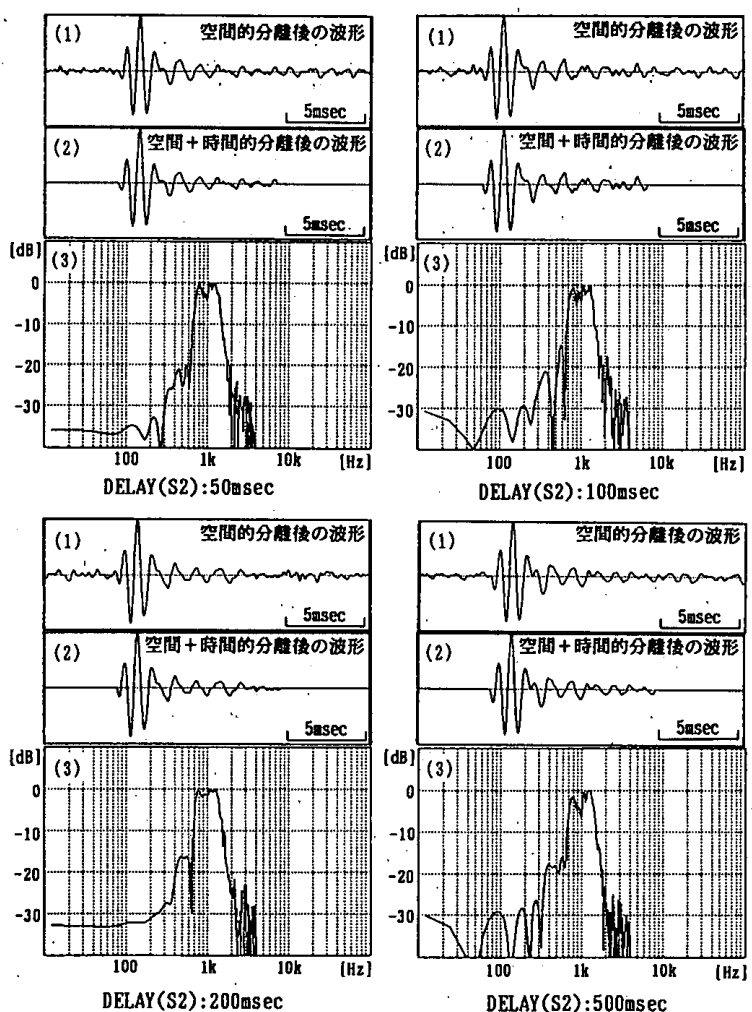

图一18 各ディレイ設定パターンごとの

（1）空間的分離後の波形

（2）空間十時間的分離による抽出波形

（3）抽出波形のパワースペクトル

ディレイ設定に応じた距離のところに仮想音源が算出さ れており，また，その座標も理論值と良い対応を示して いることから，実音場において，ある程度反射音密度が 大きい場合でも，正四面体頂点法により仮想音源が算出 されていることがわかる。

次に，この算出された仮想音源に向けて球面上配置マ イクロホンシステムで指向合成を行った。今回は図一17 に示すような指向特性で約 $350 \mathrm{~Hz} \sim 5600 \mathrm{~Hz}$ までの約 4 オクターブ帯域を対象に解析を行った。図一18には, 各ディレイ設定パターンごとに，（1），指向性受音によ り空間的分離を行った後の波形，(2) さらにその波形 を正四面体頂点法で得られた S 2 による仮想音源（図一 16）の時系列上の到達時間から，512 デー夕分の時間空 で切りとり，時間的分離を行った波形，(3)(2) で得 られた空間的，時間的分離を行った後の波形のパワース ペクトルを示す。

この抽出された波形（2）を図一13に示した無響室 での抽出対象波形と比較して見ると，時系列後半に他の 反射音によるものと思われるレベルの小さな差異が認め られるものの，図一14に示した複数の音波が干渉して いる応答波形の中から，1 kHz トーンバースト波形が, ビのディレイ設定においても精度良く抽出されているこ とがわかる。また，抽出波形のパワースペクトルを図一 13 に示したトーンバースト波形のパワースペクトルと 
比較してみると, 抽出した波形のパワースペクトルの低 音域と高音域に，他の反射音もしくは暗騒音の影響と思 われるエネルギーが混在しているが，各ディレイ設定と も, $1 \mathrm{kHz}$ オクターブ带域のトーンバーストのスペクト ルとして, $20 \mathrm{~dB}$ 程度の $\mathrm{S} / \mathrm{N}$ 比をもって抽出されてい る。

以上のように, 比較的反射音密度の大きい小ホールで, 反射音密度が変化するインパルス応答の各時間帯におい て,個々の反射音特性の抽出を試みた結果, 本手法によっ て個々の反射音が比較的精度良く抽出できることが確認 された。

\section{5. 実音場における解析例}

実音場への適用例として，サントリーホールにおいて 図一19に示すような音源, 受音点位置で測定を行い, 本手法により， $683 \mathrm{msec}$ までの解析を行った。

抽出した反射音の時系列特性の例を直接音波形ととも に図一20に示す。(1) は直接音波形であり，(2)（4) は，正四面体頂点法で得られた反射音到来方向と到達時 間から検討すると，それぞれ（2）ステージ後壁，（3） ステージ側壁，（4）浮き雲反射板からの反射音波形で あることがわかる。これらの反射音波形は，伝搬してき た壁面の伝達関数により, 直接音波形に比して変化して いる。

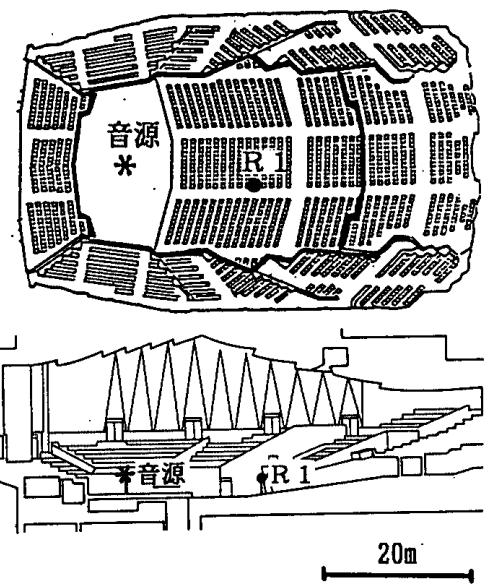

図一19 サントリーホールにおける測定配㯰図
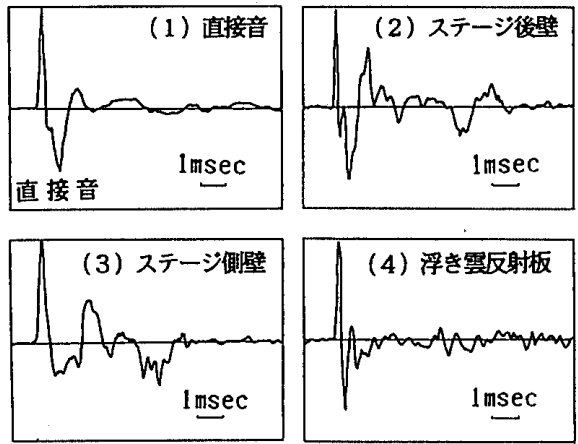

図一20 直接音波形と本手法により抽出された反射音波形の例
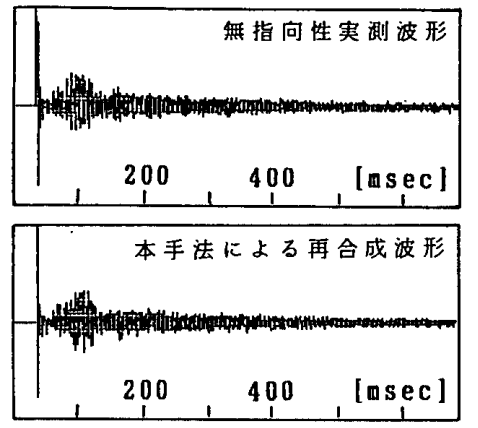

図一-21 無指向性実測波形と抽出した反射音波形の再合成波形

このように，本手法では音場の初期応答において，正 四面体頂点法により, 音波の到来方向と到達時間から音 波の伝搬してきた壁面を見いだし，さらに球面上配置マ イクロホンシステムによる計測と組み合わせることによ り，その反射音波形を観察することが可能となる。また， そのフーリエ変換からパワースペクトルによる音場の解 析が可能となる。

なお，今回は便宜上，直接音デー夕の継続時間に相当 するデー夕数の 512 データの時間空で切りとっている。 初期反射音の例であるため， 512 データ内でほぼ収束し ているが，多次回反射した反射音の波形の継続時間は一 定ではないので，この点については今後の検討が必要で ある。

本手法の検証の一つとして，抽出した反射音波形を再 合成し，無指向性の実測波形と比較して図一21に示す。 これを見ると，抽出の際に反射音のピーク值だけでなく 波形として抽出しているために， $683 \mathrm{msec}$ までの解析 では本手法による顕著なエネルギー欠損は生じておら ず，良い対応を示している。

\section{6. 周波数別仮想音源分布の算出}

音場の方向情報として，仮想音源分布を周波数別に算 出できれば，より詳細に音場を観察することができる。

仮想音源の周波数情報の算出に関しては，山崎らが近 接 4 点法で得られたインパルス応答に約 $10 \mathrm{msec} の$ 時間 空を順次設定し，短時間インテンシティの手法を用い， 周波数別の仮想音源分布を算出して音場の可視化を行っ ている415!。これは，周波数別の方向情報を視覚的に把 握できる有効な手法である。しかし，大きさを固定した 時間窓を時間移動させ, その中の短時間インテンシティ を計算する手法であるので, 得られる仮想音源の数が, 時間経過や音場の違いによらず一定になってしまう。ま た，図一22に示すように，空内に複数の波形が混在し たり，空の境界が波形を分断したりする場合，クロスス ペクトル法で算出される短時間インテンシティベクトル が周波数ごとに異なり，仮想音源位置が周波数ごとに大 きく異なることが考えられる。

さらに，それらの仮想音源位置は，個々の音波の真の 


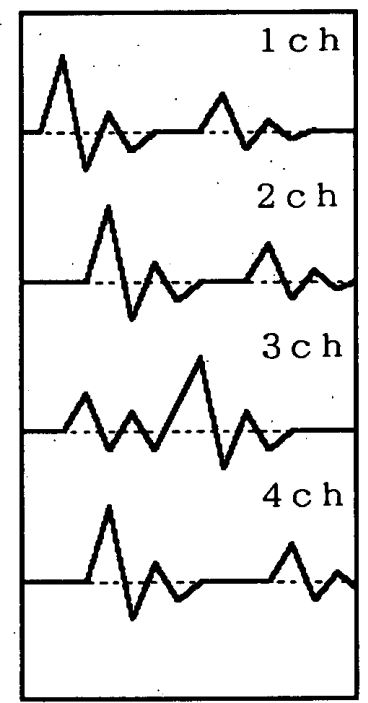

密内に複数の音波か 混在する場合

図一22 時間空内に複数の反射音が混在する場合

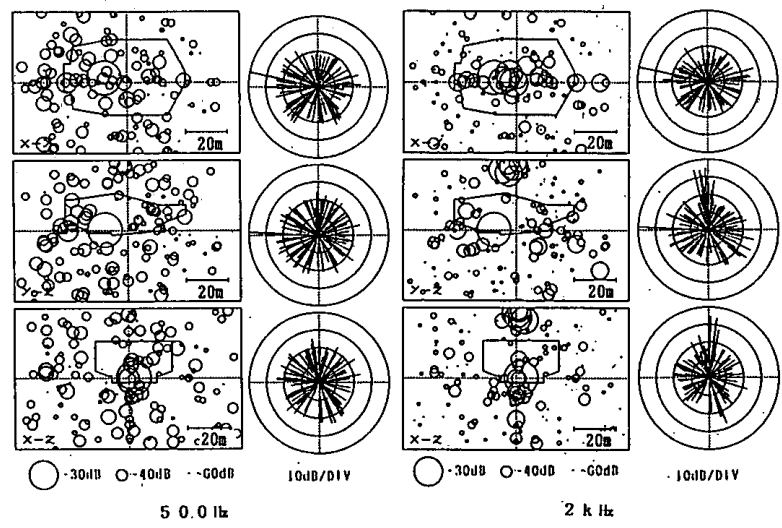

図一23 サントリーホールでの本手法による周波数別仮想音源 分布

到来方向ではなく，悹内の複数音波による合成べクトル 方向に算出される。したがって，短時間インテンシティ により得られる周波数別仮想音源分布は，受音点に到来 する反射音個々の特性の把握とは意味が異なると考えら れる。

筆者らの手法は，図一22 のように複数の音波が同一 㥶内に混在する場合でも，分離検出が可能な正四面体頂 点法により反射音の到来方向を算出した後，その個々の 反射音波形の抽出を行い，抽出した個々の反射音波形の オクターブバンドレベルを求めて周波数別の仮想音源分 布を算出する。したがって，受音点に到来する個々の反 射音に仮想音源が対応しており，周波数ごとの仮想音源 位置は変らず，周波数ごとのレベルのみが異なり，近接 4 点法で算出される周波数別仮想音分布とは意味が異な る。

サントリーホールの受音点 R 1 で本手法により抽出 した個々の反射音波形をフーリエ変換してオクターブバ
ンドレベルを求め，図一 23 に示すような $500 \mathrm{~Hz}$ と 2 $\mathrm{kHz}$ の周波数別仮想音源分布を算出した。これらを見 ると, $500 \mathrm{~Hz}$ に比較して $2 \mathrm{kHz}$ では全体的に仮想音源 のレベルが小さくなっているが，浮き雲反射板からの反 射音のレベルは $2 \mathrm{kHz}$ の方が大きくなっている。また， 指向特性を見ると， $2 \mathrm{kHz}$ において浮き雲反射板からの 反射音によって，上方向に強い指向性を示している。

このように，個々の反射音の到達時間, 到来方向とそ の特性を波形として抽出しておけば，得たい情報によっ て，時間と周波数と空間を任意に選択しながら，たとえ ば任意方向の任意指向角で方向別インパルス応答を算出 したり，周波数別仮想音源分布のような情報に加工して 音場を観察することが可能となる。

\section{7. まとめ}

今回，正四面体頂点法で得られる反射音の到達時間と 到来方向の情報をもとに, 球面上配置マイクロホンシス テムによる個々の反射音の空間的分離，さらに時間的分 離による手法を組み合わせることで，多数の反射音が到 来する室内音場における個々の反射音特性抽出手法を開 発し，単板反射実験と実音場での検証実験，および実音 場での周波数別仮想音源分布の解析例により, 初期応答 において音場の物理的な特徴をより詳細に観察できる可 能性を示した。

このことから, 本手法によって, 正四面体頂点法で得 られた音波の到達時間, 到来方向, レベルといった方向 情報に，周波数情報を付加して，補完することが可能に なったといえる。

\section{参考文献}

1) Yamazaki,. Y. \& Ito, T. : Measurement of spatial information in sound field by closely located 4-point microphone method., J. Acoust, Soc. Jpn. (E) 10, 2 pp. $101 \sim 110,1989$

2) 関口克明, 木村 翔, 羽入敏樹, 松本英一郎：4 チャン ネルマイクロホンシステムを用いた正四面体頂点法によ る室内音場の解析, 日本建築学会計画系論文報告集, 第 414 号, pp. 1 11, 1990.8

3）羽入敏樹，木村 翔, 関口克明：球面上配置マイクロホ ンシステムを用いた室内音場における任意方向インパル 応答測定手法の開発、日本建築学会計画系論文報告集, 第 445 号, pp. 9 - 17, 1993.3

4），清水信正，鈴木大介，村田清孝，伊勢史郎，山崎芳男, 伊藤 毅：近接 4 点法へのインテンシティの適用，日本 音響学会講演論文集, 1-8-10,1987.10

5）清水信正, 金 允起, 中村聡延, 山崎芳男, 伊藤 毅： 近接 4 点法を用いた短時間インテンシティによる音場の 評価, 日本音響学会講演論文集，1-7-2，1988.3

(1993 年 3 月 10 日原稿受理, 1993 年 7 月 20 日採用決定) 